\title{
ALLOCATION OF MARITIME TASK FORCE PERSONNEL UNIFIL CONTINGEN BASED ON ANALYSIS WORK LOADS
}

\author{
Ahmadi $^{1}$, Okol Sri Suharyo ${ }^{2}$, Arimbo $^{3}$, Aab Abdul Wahab ${ }^{4}$ \\ 1,2,3,4 Indonesian Naval Technology College, \\ STTAL-Bumimoro-Morokrembangan, Surabaya 60187, Indonesia
}

\begin{abstract}
The workload of an organization is related to the efficient and effective utilization of human resources so that it can realize the vision, mission and objectives of the organization. Various methods are used to optimize the number of personnel in an organization, so that each task can be completed effectively and efficiently. KRI Diponegoro-365 personnel as the TNI Maritime Task Force, the Garuda Contingent can not be separated from the problems regarding the lack of conformity to workload with the allocation of the number of available personnel. To overcome this, an analysis of workload measurement is needed which can then be used for determine the allocation of the right number of personnel needed in each division. This study uses the measurement of NASA-TLX mental workload and physical workload according to TNI Roles. Both of these methods are then compared between mental and physical burden that occurs. From the results of the comparison it was found that physical workload is needed in the completion of tasks in each division. After a comparison, then the determination of the allocation of the number of personnel will be carried out using the physical workload approach based on the description of the tasks in each division. The results of the calculation will then show the division that has excess or lack of personnel. The overall results obtained from this study, can be concluded that the number of maritime task force personnel using the Diponegoro class $K R I$ is appropriate, but the allocation of personnel in each division needs to adjust to the existing workload.
\end{abstract}

Keywords: Workload, NASA-TLX (Task Load Index), Number of Military Personnel.

\section{INTRODUCTION}

The constitutional mandate of the Republic of Indonesia at the opening of the 1945 Constitution paragraph 4 states that one of Indonesia's national goals is to participate in bringing about world peace. This goal is carried out together with other countries under the banner of the United Nations (UN) in order to create a world that is peaceful, safe and peaceful. In realizing this goal Indonesia has carried out the sending of TNI forces as part of itfrom the UN peacekeeping mission since the Garuda I contingent in 1957. For the Indonesian people, the participation of the TNI contained very important meanings, both in terms of political interests and aspects of military interests. This shows the international community, that the Indonesian people are a world that loves an orderly, peaceful and just world. For the Navy, this is an implementation of the Law. No. 34 concerning TNI Article 9, namely carrying out the duties of Navy diplomacy in order support foreign policy set by the government. Since 2009 the Indonesian Navy under the PMPP TNI has sent its sea power consisting of 1 (one) KRI and 1 (one) Heli BO-105 (onboard) to join the Maritime Task Force (MTF) of the United Nations 
Interim Force In Lebanon (UNIFIL) operating in the operational area (Rahops) / Lebanese waters. Until 2016 was the delivery of the ninth UNIFIL Maritime Task Force (MTF).

MTF UNIFIL is a maritime task force under the United Nation (UN) which has been established since October 2006, due to land mark conflicts between Israel and Lebanon. The existence of the MTF is to assist the Lebanese navy in monitoring territorial waters, securing the coastline and preventing the entry of weapons and materials through Lebanese waters. MTF was formed at the request of the Lebanese government through the mandate of the United Nation Security Council Resolution 1701 (2006). MTF operations are delegated by UNIFIL Force Commander to MTF Commander held by an officer with a two-star rank onboard on Flag Ship. There are 15 countries that have contributed to MTF, namely Bangladesh, Belgium, Brazil, Bulgaria, Denmark, France, Germany, Greece, Indonesia, Italy, the Netherlands, Norway, Spain, Sweden and Turkey.

Assignments carried out by the maritime task force of the TNI UNIFIL Garuda Contingent very different from the operations and training activities carried out domestically (Indonesia). The task force sent will be in charge for 10 (ten) months with details of 8 (eight) months in the Maritime Operation Area (AMO) and 2 (two) months for sea traffic. The task force had to travel approximately $7000 \mathrm{Nm}$ to Lebanon by stopping in several countries. Almost every stopover in a transit country, the activities carried out are diplomacy. Diplomatic activities carried out include cocktail parties, joint sports and visits to government agencies in transit countries. Therefore ships and preservatives must be thoroughly prepared. Ships must meet the standards set by the United Nations. Ranging from technical equipment, machinery, weapons, sensors, navigation equipment, communication equipment, accommodation and fulfill health requirements.

Activities carried out after arriving in Lebanon are welcome, briefing and inspection from MTF staff. After being declared Inchop then first assignment begins. Each day the task force will receive a Daily Intention Message (DIM) containing information and emphasis from staff personnel, intelligence, operations, planning, logistics, communication and training staff. In the DIM mention the situation and conditions of Lebanon, the sector in the Area of Maritime Operation (AMO), which is a duty and responsibility that must be secured, the assignment of elements of the task becomes Maritime Interdiction Operation Commander (MIO), Helicopter Element Coordinator (HEC), Anti-Air Warfare Commander (AAWC) and activities operations and serial exercises that must be carried out with elements from other countries and the Lebanese Armed Force (LAF). The proportion of attendance at $\mathrm{AMO}$ and berth on the dock is $70 / 30$. This means that once on task the average ship operating at sea is 5 to 6 days and only given the opportunity to dock on the pier 1 to 2 days to carry out the provision.

Task force personnel have mental and physical burdens in carrying out the tasks mentioned above. Besides the very long operating time and having to leave the family for 10 (ten) months, each person must always maintain the good name of the nation and country. Every personnel is always required to be professional in carrying out their duties. Task Force faced with the situation operational areas that are vulnerable, both at sea and on land. then the weather conditions at the AMO are changing, but the task force must continue to carry out operations. These things were a mental burden for task force personnel. While the physical burden comes from various types of operations and exercises that have been determined and determined by MTF commander 
staff. Warrant of TNI Commander Number Sprin / 521 / III / 2013 dated March 5, 2013 concerning the appointment of personnel as the TNI Maritime Task Force Konga XXVII E / UNIFIL 2013 stated that UNIFIL MTF personnel numbered 100 people including outside personnel of KRI Diponegoro-365. In accordance with the monthly report of KRI Diponegoro-365 personnel, in January 2013 the number of real PERSONNEL CHECKLIST is 102 people. So that the number of NRI / Diponegoro$365 \mathrm{KRI}$ enlisted personnel must be reduced to 20 people to carry out their duties as UNIFIL MTF. 14 people outside KRI Diponegoro-365 personnel were 7 (seven) people from helicopters and pilots, 1 (one) intelligence officer, 1 (one) information officer, 1 (one) diver member, 1 (one) Kopaska, 1 (one) doctor, 1 (one) marine officer and 1 (one) Combat Information Center (PIT) officer. So that with a reduction in the number of personnel it results in an increase in workload for each division, because some personnel have multiple tasks. In view of the duties and responsibilities that have been assigned to the task force personnel as mentioned above it is not easy, so in this case the KRI Commander Diponegoro-365 as the decision maker assisted by staff must make the right decision in determining the number of personnel in each division. The commander and staff must determine the allocation the right number of personnel for each division so that tasks can be carried out properly.
Based on the background above, in this study a load analysis will be carried out work for task force personnel in accordance with their divisions. The workload analysis is the basis for determining proportional personnel allocation.

\section{MATERIAL AND METHOD}

\subsection{Task Load Index (NASA-TLX)}

NASA-TLX method is a subjective method that is often used in measuring mental workload and physically in individuals in various industries. In the NASA TLX method, there are 6 indicators to be measured from each individuals, namely mental mental needs

Demands, Physical physical needs Demands, Temporal time needs Demands, Performance, level of business / Effort and the last is the level of frustration / Frustation (Young \& Zavelina, 2008). Of each measure of workload, there is a scale that will have to be filled by respondents. This is the first step in measuring workload. On indicators of mental / Mental needs Demand for physical needs / Temporal Demands, level of effort / Effort and level of frustration / Frustation, the scale used is low to high. Whereas for measurement of performance / Own Performance is used to scale well to bad. Explanation of indicators of mental burden in Table 1. below:

Table 1 Table of Workload Indicator Scale

\begin{tabular}{|l|c|l|}
\hline Workload Indicator & Scale & \multicolumn{1}{c|}{ Definition } \\
\hline Mental Demand (MD) & Low, high & $\begin{array}{l}\text { Mental activities and perceptions for see, remember and } \\
\text { search. Is the job easy or difficult, complex or simple, } \\
\text { loose or tight to work on a task }\end{array}$ \\
\hline Physical Demand (PD) & Low, high & Physical activity needed for doing a task \\
\hline Temporal Demand (TD) & Low, high & Pressure related to the time felt during the assignment \\
\hline
\end{tabular}




\begin{tabular}{|l|l|l|}
\hline & & take place, Is it slow, relaxed, or fast \\
\hline Performance (OP) & Good, bad & $\begin{array}{l}\text { How much success someone in a task and how satisfied } \\
\text { with the results of his work }\end{array}$ \\
\hline Effort (EF) & Low, high & $\begin{array}{l}\text { How hard is the effort or mental and physical work } \\
\text { needed to complete the task }\end{array}$ \\
\hline Frustation Level (FR) & Low, high & $\begin{array}{l}\text { Overall stress or satisfaction, } \\
\text { the complexity of the task }\end{array}$ \\
\hline
\end{tabular}

After the scale is known used to measure each indicator, the next step isdata processing to load acquisition work (Hart \& Staveland, 1988). These steps are as follows:

a. Calculate product value in a way multiplying the rating by the factor weight for each descriptor, so there are six product values for six descriptors (MD, PD, TD, OP, EF and FR).

\section{Product Value $=$ Rating $\mathbf{x}$ Weight Factor}

b. Calculating WWL (Weighted) Workload), which is the workload caused by each descriptor with equation:
$\mathbf{W W L}=\Sigma$ Product

c. Calculate WWL values in a way divide WWL by total weight that is 15 .

\section{Average of WWL $=\mathrm{WWL} / 15$}

In this research, NASA-TLX will be used as one method for knowing mentally workload later on indicates what a job is which is charged has a burden that high or low. Categorization what is meant as stated on Table 2.

Table 2 Categorization of Workloads

\begin{tabular}{|c|c|c|}
\hline Number & $\begin{array}{c}\text { Range of Mental } \\
\text { Workload }\end{array}$ & $\begin{array}{c}\text { Category } \\
\text { of Workload }\end{array}$ \\
\hline 1 & $0-29$ & Low \\
\hline 2 & $30-49$ & Medium \\
\hline 3 & $50-79$ & High \\
\hline 4 & $80-100$ & Very High \\
\hline
\end{tabular}

(Source: Raras, 2012)

\subsection{Task Approach Per Job Position}

(Kep.Men.Pan Number: Kep / 75 / M.Pan / 7/2004)

On the task approach method job assignment was chosen because of this method is a method for counting the needs of employees in the office the results of his work are abstract or diverse. On calculation with this method, sought first working time and working hours effective personnel. Only time is calculated completion of each assignment for each position

\subsubsection{Aspects of Calculation}

Basic aspects that must be note there are 3 :

a. Workload

Workload is an aspect the principal on which to base calculation. Workload needs to be set 
through work unit programs subsequently

translated into targets job for each position. b.

Average Ability Standards

Average ability standard can be a standard of ability measured from the unit of time used or unit of results.

\section{c. Working time}

The working time referred to here is effective work time, meaning time work that is effectively used for work. Effective working time consists of Effective Business Days and Effective Working Hours, that is

1) Effective working day is the number of days in calendar minus holidays and leave. The calculation is as following:

Number of days according to calendar .....day

Number of Sundays in 1 year .....day

Number of days off in 1 year .....day

Number of leave in 1 year .....day

Holidays and leave

Normative work day .....day

2) Effective working hours are the number of hours formal work is reduced by working time lost because it doesn't work (allowance) such as defecating, removing tired, eating breaks and so on. According to the rules of the TNI Commander, Perpang / 93 / XI / 2011 states that there are many unproductive work time for every member in carrying out allowance is influenced by each individual's activities are good routine or incidental. To achieve organizational goals it is necessary note the balance between organizational interests on the one hand and individual interests on the other hand.The activities of each individual who routine and incidental can be classified into several examples:

a) Personal matters (personnel related).

b) Medical examination (medica).

c) Organizational tasks outside the task organizational duties.

d Education (education).

e) Training (training).

f) Social activity.

Each unit can calculate working time which is not productive by using approach according to unit conditions local and unit characteristics. Has been determined that the amount of work time unproductive within the TNI $30 \%$ for staff and $20 \%$ for troops. In calculating working hours effective should be used for 1 week size. Here is an example of counting effective working hours:

Number of formal work hours 1 week minutes

Allowance $30 \%$ x 400 minutes 120 minutes

Effective working hours of 1 week 280 minutes

Total formal working hours in 1 week is 8 hours per day 5 days.

\subsubsection{Steps of the task load approach method:}

a. Describe the duties of each position and calculate the completion time for each of these positions. In this is due tojob description as a reference in describing the task not given for each position, but for individuals, then calculation done for each employee.

b. Enter job description and task completion time (WPT). 
C. If there are unit differences on task completion time (WPT), do it conversion to equalize time units completion of the task. In this research, completion time is equated to be minutes / ontask.

Number of employees $=$

$\Sigma$ Time for completing assignments

$\Sigma$ Effective Work Time d. In determining the number of employees needed, used formula calculation.

\section{RESULTS AND DISCUSSION}

In the data analysis phase consists of 2 (two) activities, namely data collection and data processing. As the object of research, namely KRI Diponegoro-365. The data that has been obtained will be used for processing the workload / task of each part / work unit. Personnel Checklist of Petty officer / Enlisted Rill and TNI Maritime Task Force Konga XXVIII / E UNIFIL 2013 KRI Diponegoro-365 average can be seen in the Table bellow.

Table 3. Task Force Personnel Checklist

\begin{tabular}{|c|l|c|c|}
\hline NO & \multicolumn{1}{|c|}{ DIVISION } & $\begin{array}{c}\text { REAL PERSONEL } \\
\text { CHECKLIST }\end{array}$ & $\begin{array}{c}\text { TASK FORCE } \\
\text { PERSONNEL } \\
\text { CHEKLIST }\end{array}$ \\
\hline 1 & COMMUNICATION & 6 & 6 \\
\hline 2. & NAVIGATION & 5 & 3 \\
\hline 3. & ASW & 12 & 9 \\
\hline 4. & AAW & 10 & 6 \\
\hline 5. & WEAPON DETECTION & 7 & 4 \\
\hline 6. & COMMUNICATION DET. & 6 & 6 \\
\hline 7. & MAIN ENGINE & 9 & 5 \\
\hline 8. & AUXILIARY ENGINE & 6 & 11 \\
\hline 9. & ELECTRIC CONTROL & 14 & 62 \\
\hline 10. & LOGISTIC & 82 & 6 \\
\hline & TOTAL NUMBER & & 6 \\
\hline
\end{tabular}

\subsection{Mental Workload Processing (NASA-TLX)}

The size of this method, carried out through three stages, namely calculating the value of the product multiplied by the rating by weight, calculating the Weighted Workload (WWL) value and calculating the WWVL average. The results of the recapitulation of the total WWL value and WWL average can be seen in the table.

Table 4. Category of Workload

\begin{tabular}{|c|l|l|l|c|}
\hline NO & DIVISION & $\begin{array}{l}\text { AVERAGE OF } \\
\text { WWL }\end{array}$ & $\begin{array}{c}\text { VALUE OF } \\
\text { WWL }\end{array}$ & $\begin{array}{c}\text { CATEGORY } \\
\text { OF } \\
\text { WORKLOAD }\end{array}$ \\
\hline
\end{tabular}




\begin{tabular}{|c|l|c|c|c|}
\hline 1 & COMMUNICATION & 120,33 & 80,23 & Very Hight \\
\hline 2. & NAVIGATION & 741,667 & 49,45 & Medium \\
\hline 3. & ASW & 1148,33 & 76,56 & Hight \\
\hline 4. & AAW & 1080 & 72 & Hight \\
\hline 5. & WEAPON DETECTION & 690 & 46 & Medium \\
\hline 6. & COMMUNICATION DET. & 683,333 & 45,56 & Medium \\
\hline 7. & MAIN ENGINE & 1138,33 & 75,89 & Hight \\
\hline 8. & AUXILIARY ENGINE & 1130 & 75,34 & Hight \\
\hline 9. & ELECTRIC CONTROL & 868,34 & 57,89 & Hight \\
\hline 10. & LOGISTIC & 436,667 & 29,11 & Low \\
\hline
\end{tabular}

\subsection{Processing of Physical Workloads}

The processing of this workload must first be determined regarding the active working day, the working hours of each personnel imposed on the KRI Diponegoro-365 when carrying out activities. To obtain effective working time and working hours some secondary data is obtained from the object of research. Furthermore, the data is processed to obtain effective working time, effective working hours and time to complete tasks that are borne by each person. The personnel requirements formula are as follows:

\section{$\Sigma$ Task Completion Time}

Number of personnel $=$

\section{$\Sigma$ Effective Work Time}

Table 5. The results of the recap Rounded Personnel

\begin{tabular}{|c|l|c|c|c|}
\hline NO & \multicolumn{1}{|c|}{ DIVISION } & $\begin{array}{c}\text { Total Time of } \\
\text { Task } \\
\text { Completion }\end{array}$ & $\begin{array}{c}\text { Number of } \\
\text { Personnel } \\
\text { Should Be } \\
\text { Needed }\end{array}$ & $\begin{array}{c}\text { Total } \\
\text { Rounded } \\
\text { Personnel }\end{array}$ \\
\hline 1 & COMMUNICATION & 16.470 & 6.127 & 7 \\
\hline 2. & NAVIGATION & 7.030 & 2.615 & 3 \\
\hline 3. & ASW & 19.455 & 7.237 & 8 \\
\hline 4. & AAW & 19.155 & 7.126 & 8 \\
\hline 5. & WEAPON DETECTION & 13.560 & 5.044 & 5 \\
\hline 6. & COMMUNICATION DET. & 10.560 & 3.958 & 4 \\
\hline 7. & MAIN ENGINE & 17.271 & 6.473 & 7 \\
\hline 8. & AUXILIARY ENGINE & 16.715 & 6.218 & 7 \\
\hline 9. & ELECTRIC CONTROL & 11.155 & 4.181 & 5 \\
\hline 10. & LOGISTIC & 22.275 & 8.348 & 9 \\
\hline
\end{tabular}

\subsection{Comparison of the Value of Mental and}

\section{Physical Workloads}

In this comparison, the physical workload category is adjusted to the mental workload with 
NASA-TLX, which is made into 4 categories including low, medium, high and very high categories.In physical workload, categories are made into several ranges, namely by determining the quartile point of the minimum and maximum values for the total time of completion of each task

Table 6. Physical Workload Value

\begin{tabular}{|c|c|c|}
\hline $\begin{array}{c}\text { Range of Physical } \\
\text { Workload }\end{array}$ & $\begin{array}{c}\text { Category } \\
\text { of Workload }\end{array}$ & $\begin{array}{c}\text { Value of } \\
\text { Physical } \\
\text { Workload }\end{array}$ \\
\hline$\leq 11.154$ & Low & 1 \\
\hline $11.155-16.591$ & Medium & 3 \\
\hline $16.592-19.154$ & High & 4 \\
\hline$>19.154$ & Very High & 2 \\
\hline
\end{tabular}

Table 7. Value of Mental Workload

\begin{tabular}{|c|c|c|}
\hline $\begin{array}{c}\text { Range of Mental } \\
\text { Workload }\end{array}$ & $\begin{array}{c}\text { Category } \\
\text { of Workload }\end{array}$ & $\begin{array}{c}\text { Value of Mental } \\
\text { Workload }\end{array}$ \\
\hline $0-29$ & Low & 1 \\
\hline $30-49$ & Medium & 2 \\
\hline $50-79$ & High & 4 \\
\hline $80-100$ & Very High & 4 \\
\hline
\end{tabular}

The average workload value equation of the two methods:

$$
z=\frac{x+y}{2}
$$

Table 8 below is the average workload value between the value of the mental workload and the value of the physical workload.

Table 8. Category of Workload

\begin{tabular}{|c|c|c|}
\hline $\begin{array}{c}\text { Coefficient value of } \\
\text { Workload }\end{array}$ & $\begin{array}{c}\text { Category } \\
\text { of Workload }\end{array}$ & Remark \\
\hline $0-29$ & Low & $\begin{array}{c}\text { No Need for Addition or } \\
\text { Reduction of Personnel }\end{array}$ \\
\hline $30-49$ & Medium & $\begin{array}{c}\text { Possible for Addition or } \\
\text { Reduction of Personnel }\end{array}$ \\
\hline $50-79$ & High & $\begin{array}{c}\text { Need Addition of } \\
\text { Personnel }\end{array}$ \\
\hline $80-100$ & Very High & $\begin{array}{c}\text { Need Addition of } \\
\text { Personnel }\end{array}$ \\
\hline
\end{tabular}


Table 9. The result of consideration of the number of person

\begin{tabular}{|c|c|c|c|c|c|c|}
\hline No & Division & $\begin{array}{l}\text { Value of } \\
\text { Mental } \\
\text { Workload } \\
\text { (x) }\end{array}$ & $\begin{array}{l}\text { Value of } \\
\text { Physical } \\
\text { Workload } \\
\text { (y) }\end{array}$ & $\begin{array}{l}\text { Average of } \\
\text { Workload } \\
\text { value }(z)\end{array}$ & Category & Remark \\
\hline 1. & COMMUNICATION & 4 & 2 & 3 & Very High & $\begin{array}{l}\text { No Need for Addition or } \\
\text { Reduction of Personnel }\end{array}$ \\
\hline 2. & NAVIGATION & 2 & 1 & 1.5 & Low & $\begin{array}{c}\text { Possible for Addition } \\
\text { or } \\
\text { Reduction of Personnel }\end{array}$ \\
\hline 3. & $\overline{\text { ASW }}$ & 3 & 3 & 3 & Very High & $\begin{array}{l}\text { Need Addition of } \\
\text { Personnel }\end{array}$ \\
\hline 4. & AAW & 3 & 3 & 3 & Very High & $\begin{array}{c}\text { Need Addition of } \\
\text { Personnel }\end{array}$ \\
\hline 5. & $\begin{array}{l}\text { WEAPON } \\
\text { DETECTION }\end{array}$ & 2 & 2 & 2 & Medium & $\begin{array}{l}\text { Possible for Addition } \\
\text { or } \\
\text { Reduction of Personnel }\end{array}$ \\
\hline 6. & $\begin{array}{l}\text { COMMUNICATION } \\
\text { DET. }\end{array}$ & 2 & 1 & 1.5 & Medium & $\begin{array}{l}\text { Possible for Addition } \\
\text { or } \\
\text { Reduction of Personnel }\end{array}$ \\
\hline 7. & MAIN ENGINE & 3 & 3 & 3 & Very High & $\begin{array}{c}\text { Need Addition of } \\
\text { Personnel }\end{array}$ \\
\hline 8. & $\begin{array}{l}\text { AUXILIARY } \\
\text { ENGINE }\end{array}$ & 3 & 3 & 3 & Very High & $\begin{array}{c}\text { Need Addition of } \\
\text { Personnel }\end{array}$ \\
\hline 9. & $\begin{array}{l}\text { ELECTRIC } \\
\text { CONTROL }\end{array}$ & 3 & 2 & 2.5 & Medium & $\begin{array}{l}\text { Possible for Addition } \\
\text { or } \\
\text { Reduction of Personnel }\end{array}$ \\
\hline 10. & LOGISTIC & 1 & 4 & 2.5 & Medium & $\begin{array}{l}\text { Possible for Addition } \\
\text { or } \\
\text { Reduction of Personnel }\end{array}$ \\
\hline
\end{tabular}

\subsection{Determination of the Number of Optimal} Personnel

The basic calculation of the number of personnel is in accordance with the KEP / 75 / M.PAN / 7/2004 method, then adjusted to the results of consideration according to table 4.10 to determine the optimal number of personnel. then next Table 10. will show a comparison of the number of 
Table 10. A comparison of the number of optimal personnel

\begin{tabular}{|c|l|c|c|l|}
\hline No & \multicolumn{1}{|c|}{ Division } & $\begin{array}{c}\text { Optimum } \\
\text { Number } \\
\text { Personnel }\end{array}$ & $\begin{array}{c}\text { Number } \\
\text { Personnel of Task } \\
\text { Force }\end{array}$ & \multicolumn{1}{|c|}{ Remark } \\
\hline 1. & COMMUNICATION & 7 & 6 & 1 personnel added \\
\hline 2. & NAVIGATION & 3 & 3 & $\begin{array}{l}\text { No need addition or } \\
\text { reduction of personnel }\end{array}$ \\
\hline 3. & ASW & 8 & 9 & 2 Personnel Added \\
\hline 4. & AAW & 8 & 6 & 1 Personnel reduced \\
\hline 5. & WEAPON DETECTION & 5 & 6 & 1 Personnel reduced \\
\hline 6. & COMMUNICATION & 4 & 4 & $\begin{array}{l}\text { No need for Addition or } \\
\text { Reduction of Personnel }\end{array}$ \\
\hline 7. & MAIN ENGINE & 7 & 6 & 1 personnel added \\
\hline 8. & AUXILIARY ENGINE & 7 & 6 & 1 personnel added \\
\hline 9. & ELECTRIC CONTROL & 5 & 5 & $\begin{array}{l}\text { No need for Addition or } \\
\text { Reduction of Personnel }\end{array}$ \\
\hline 10. & LOGISTIC & 9 & 11 & 2 Personnel reduced \\
\hline
\end{tabular}

\section{CONCLUSION}

The workload of personnel when carrying out their duties as Unifil MTF indicates the existence of excess and lack of workload received by each personnel in their respective divisions. In accordance with calculations with the mental workload approach, NASA-TLX, it is known that the largest mental workload is experienced by the MPK division with an average WWL value of 75,889 and the lowest mental workload experienced by the division detkom with a value of the average WWL is 45,556 . While the calculation according to the task load approach of each position is in accordance with PerMENPAN or TNI warplanes physically, the Minlog division has the highest total task completion time, which is 22,275 minutes.

It was found that the value of mental workload in all divisions has a value of 3 with a high category except the Navigation, Teksen and
Detkom divisions which have load 2 or moderate categories. Whereas value Minlog division's physical workload has the highest load value, 4 or very high category. PBA, PAA, MPK and MB divisions have the value of physical load 3 or high category. The Communication, Text and Listrol Division has the value of physical load 2 or in the medium category. The Navigation and Detection Division has the value of physical load 1 or low category. So that this can be concluded that the mental workload is more dominant than the physical workload on the assignment

The optimal number of personnel per division is in accordance with the physical workload based onPerMENPAN namely KEP / 75 / M.PAN / 7/2004, namely the Communication division required 7 personnel, Navigation division 3 personnel, PBA division 8 personnel, PAA division 8 personnel, Detkom division 4 personnel, Teksen 
division 5 people personnel, MPK division 7 people, division MB 7 personnel, Listrol division 5 personnel and divisions Minlog 9 personnel So for the overall optimal number of personnel needed for enlisted / enlisted personnel is 63 personnel.

\section{REFERENCES}

Arumsari, R. 2013. Designing Requirements for Optimal Number of Employees Based on Workload Analysis to Increase Work Productivity (case study: modern clinic dasa medika surabaya). Final Project FTI ITS Industrial Engineering Student, Surabaya.

Endriyanto, W. 2014. Optimization of the number of public relations personnel based on workload analysis according to job description and job analysis according to FES (Factor Evaluation System). Final Project STTAL Industrial Management Engineering Student.

Hart, S.G. \& Staveland, L.E. 1988. Development of NASA-TLX (Task Load Index): Result of empirical and theoretical research. In: Human Mental Workload. (Eds. Peter A. Hancock and Najmedin Meshkati), Elsevier Science Publisher, Norht Holland, 139-184.

Hasibuan, S.P., 2000. Human Resource Management, PT. Bumi Aksara, Jakarta.

MenPAN, 2004, Guidelines for Calculating Employee Needs Based on Workload in the Context of Formation of Civil Servants Formation. Decision Number: KEP / 75 / M.PAN / 7/2004, Jakarta.

Pranoto and Retnowati, 2015. Analysis of Workload, PPM Manajemen, Jakarta.

Rahadian, R., Workload Analysis Using Work Sampling and NASA-TLX to determine the number of operators (case study: PT XYZ).
Raras Mayang Arsi, 2012. Analysis of Workload to Determine Optimal Amount of Employees and Mapping of Employee Competencies Based on Job Description (Case Study: Department of Industrial Engineering, ITS, Surabaya).

Simanjuntak, R. A., 2010, Analysis of Mental Workloads with NASA-TLX Method, Final Project Student of Industrial Engineering Department, AKPRIND Institute of Science \& Technology, Yogyakarta.

Victor, 2016. Optimization Model of Labor Based On Workload At Production Process.

Wignjosoebroto, S., 2008, Ergonomics of Motion and Time Study, Guna Widya, Jakarta.

Young, G. \& Zavelina, L. 2008. "Assessment of Workload Using NASA's Task Load Index in Perianesthesia Nursing". 